\title{
Transcriptional Activity of Neurotrophins Genes and Their Receptors in the Peripheral Blood in Patients with Thyroid Diseases in Bukovinian Population of Ukraine
}

\author{
Iryna Kamyshna ${ }^{1 *}$, Aleksandr Kamyshnyi ${ }^{2}$ \\ ${ }^{1}$ Department of Medical Rehabilitation, I. Horbachevsky Ternopil National Medical University, Ternopil, Ukraine; ${ }^{2}$ Department of \\ Microbiology, Virology, and Immunology, I. Horbachevsky Ternopil National Medical University, Ternopil, Ukraine
}

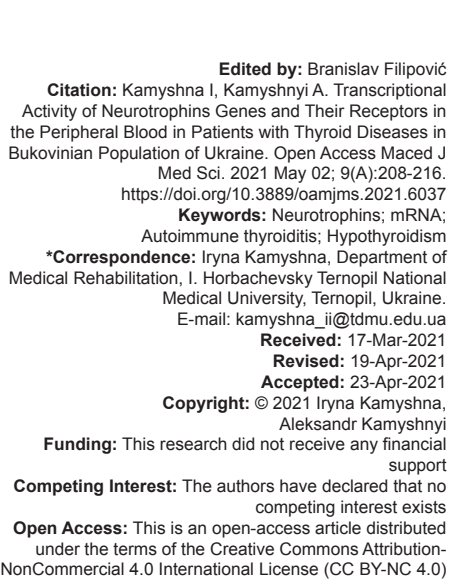

\section{Abstract}

AIM: Thyroid hormone ( $\mathrm{TH})$ has an especially strong impact on central nervous system development and $\mathrm{TH}$ deficiency has been shown to result in severe mental retardation. It is crucial to identify compensatory mechanisms that can be involved in improving cognitive function and the quality of life of patients with hypothyroidism.

METHODS: We used the pathway-specific PCR array (Neurotrophins and Receptors $\mathrm{RT}^{2}$ Profiler PCR Array QIAGEN, Germany) to identify and validate neurotrophins genes and their receptors expression in patients with thyroid pathology and control group.

RESULTS: The analysis of gene expression of neurotrophins and their receptors showed that CRHBP, FRS2, FRS3, GFRA1, GFRA2, Glial maturation factor-beta (GMFB), nerve growth factor (NGF), NRG2, NRG4, NTF4, TRO, and VGF significantly decreased their expression in Group 3, which includes the patients with post-operative hypothyroidism. The patients with primary hypothyroidism stemming from AIT had significantly reduced expression of CRHBP, GFRA1, GFRA2, GMFB, NGF, PTGER2, and VGF, while the expression of NRG4 and TRO increased. In Group 3, which includes the patients with AIT and elevated serum anti-Tg and anti-TPO autoantibodies, the mRNA levels of GFRA2, NGF, NRG2, NTF4, NGF, and PTGER were reduced, and the expression of CRHBP, FRS2, FRS3 GFRA1, GMFB, NRG4, TRO, and VGF significantly increased.

CONCLUSION: These results indicate significant variability in the transcriptional activity of the genes of encoding for neurotrophins and their receptors in the peripheral blood in people with thyroid diseases.

\section{Introduction}

Hypothyroidism is a common condition with an incidence of $8 \%$ in the adult population [1]. Its clinical picture includes cognitive, attention, and mental disorders such as depression, suggesting hippocampal alterations [2]. Most symptoms usually recede following thyroid hormone ( $\mathrm{TH}$ ) replacement therapy, but some persist, especially in the cases of long-term hypothyroidism. TH has an especially strong impact on central nervous system (CNS) development, and $\mathrm{TH}$ deficiency has been shown to result in severe mental retardation [3]. While early identification and treatment using replacement therapy can prevent or ameliorate developmental defects, there is evidence that certain neurocognitive impairments may still persist [4]. Although acute effects of TH deficiency have been extensively studied, little is known about its long-term consequences on the cellular function or the capacity of the brain for complete recovery from postnatal hypothyroidism.

In previous studies, we demonstrated that autoimmune thyroiditis (AIT) and hypothyroidism can affect the transcription of mRNA for the genes involved in nerve impulse transmission and cell cycle in a genespecific manner [5], [6], [7]. These changes in gene expression can also play a role in the development of neurological complications related to thyroid pathology, but the model of neurotrophin expression and its regulation under pathological conditions is not yet complete. Therefore, it is crucial to identify compensatory mechanisms that can be involved in improving cognitive function and the quality of life of patients with hypothyroidism.

While neurotrophins were initially described as modulators of cell growth and maintenance in the nervous and immune systems, their role in various pathophysiological conditions is now receiving considerableinterest. Changesinneurotrophinexpression within a tissue can indicate an ongoing pathophysiological process. Many genes for neurotrophins and their receptors are not only transcribed but also translated in blood cells (https://www.proteinatlas.org). Consequently, neurotrophins detected in the blood circulation system, and in their local expression, are assumed to reflect systemic neurotrophin levels. Transcriptional induction or 
gene repression is an important indicator of the severity of pathological changes in tissues [8], [9], [10], [11]. This study aims to analyze the transcriptional activity of genes for neurotrophins and their receptors in peripheral blood cells in patients with thyroid gland diseases. Neurotrophinspecific biomarkers in the blood can be then used as a prognostic marker for the risk of developing neurological and psychological complications comorbid with thyroid pathology. We are using PCR arrays to determine the effect of $\mathrm{TH}$ and serum autoantibodies, such as anti-thyroglobulin (anti-TG) antibody and anti-thyroid peroxidase antibody (anti-TPO), on the transcription of genes encoding neurotrophins and their receptors in the patients with primary hypothyroidism stemming from AIT and post-operative hypothyroidism as well as the patients with AIT and elevated serum autoantibodies, such as anti-Tg and anti-TPO.

\section{Methods}

One hundred fifty-three patients with thyroid pathology were enrolled in the study. They were divided into 3 groups: Group 1 included 16 patients with postoperative hypothyroidism; group 2 included 65 patients with hypothyroidism resulting from AIT; and group 3 included 72 patients with AIT and elevated serum an anti-Tg and anti-TPO antibodies. Control group included 25 healthy individuals, which were recruited randomly, without matching for age or sex. Clinical characteristics of the subjects are shown in Table 1.

Hypothyroidism was diagnosed following the recommendations of the American Association of Clinical Endocrinologists 2012. The diagnosis of AIT was based on detected circulating antibodies to thyroid antigens (anti-TPO and anti-TG) and reduced echogenicity on thyroid sonogram in a patient with relevant clinical features [12].

Blood specimens were collected between 8 and $10 \mathrm{AM}$ after an overnight fast. Free thyroxine (fT4) (normal range 6.0-13.0 pmol/L for males and 7.0-13.5 $\mathrm{pmol} / \mathrm{L}$ for females), thyroid-stimulating hormone (normal range $0.3-4.0 \mathrm{mlU} / \mathrm{mL}$ ), anti-TPO (normal range $0-30 \mathrm{IU} / \mathrm{mL}$ ), and anti-TG (normal range $0-65 \mathrm{IU} / \mathrm{mL}$ ) antibody levels were determined in every individual using STAT FAX303/Plus analyzer (Awareness Technology Inc, USA).
Patients under the age of 18 or those suffering from malignancy, inflammation associated rheumatic diseases or acute/chronic infection, diabetes mellitus, cardiovascular or cerebrovascular diseases, chronic hepatic or renal diseases, as well as pregnant women and those using any drugs that could interfere with thyroid function, were excluded from the study.

We used a pathway-specific PCR array (Neurotrophins and Receptors RT2 Profiler PCR Array, QIAGEN, Germany) to identify and verify cytokines and receptor pathways-associated gene expression in randomly selected 12 individuals from each group using real-time PCR due to the procedure described below.

\section{Experimental procedures}

\section{RNA isolation}

Total RNA was isolated from white blood cells using NucleoZOL (Macherey-Nagel, Germany) according to the manufacturer's instructions. NucleoZOL is designed for the isolation of total RNA (small and large RNA) in a single or separate fraction from a variety of sample materials, such as cells, tissue, and liquids of human or animal origin. White blood cells were lysed and homogenized in NucleoZOL reagent based on guanidinium thiocyanate and phenol.

\section{cDNA synthesis}

The RNA quality was determined and it was reverse transcribed. The concentration and quality of the isolated total RNA were determined on a NanoDrop spectrophotometer (Thermo Scientific ${ }^{\mathrm{TM}}$, USA). For the reverse transcription procedure with a cDNA conversion $\mathrm{RT}^{2}$ First Strand Kit (QIAGEN, Germany, Cat. no. 330401), RNA samples with the following parameters were selected: Ratio A260/A280 within the range of 1.8-2.2.

The RT2 HT First Strand Kit procedure comprises two steps: Elimination of genomic DNA contamination and reverse transcription, which enable fast and easy handling of 96 RNA samples simultaneously. After genomic DNA elimination, the RNA sample undergoes reverse transcription with an RT master mix, as well as random hexamers and oligo-dT prime reverse transcription to capture more difficult-to-detect genes.

Table 1: Clinical characteristics of the subjects

\begin{tabular}{lllll}
\hline Variable & $\begin{array}{l}\text { Control group } \\
(\mathrm{n}=25)\end{array}$ & $\begin{array}{l}\text { Patients with post-operative } \\
\text { hypothyroidism (Group 1) }(\mathrm{n}=16)\end{array}$ & $\begin{array}{l}\text { Patients with hypothyroidism as } \\
\text { a result of AIT }(\text { Group 2) }(\mathrm{n}=65)\end{array}$ & $\begin{array}{l}\text { Patients with AIT with rising serum anti-Tg and } \\
\text { anti-TPO autoantibodies }(\text { Group 3) }(\mathrm{n}=72)\end{array}$ \\
\hline The age (years) & $46.08 \pm 14.58$ & $47.30 \pm 12.27$ & $46.72 \pm 15.49$ & $45.02 \pm 13.65$ \\
fT4 (pmol/L) & $8.91 \pm 0.97$ & $3.44 \pm 0.31$ & $4.13 \pm 0.52$ & $8.51 \pm 0.82$ \\
Thyroid-stimulating hormone $(\mathrm{mlU} / \mathrm{mL})$ & $2.67 \pm 0.52$ & $8.61 \pm 0.84$ & $7.09 \pm 0.50$ & $2.38 \pm 0.62$ \\
Anti-TPO $(\mathrm{IU} / \mathrm{mL})$ & $34.04 \pm 3.70$ & $36.13 \pm 2.78$ & $380.62 \pm 73.42$ & $330.36 \pm 50.23$ \\
Anti-TG $(\mathrm{IU} / \mathrm{mL})$ & $15.32 \pm 1.97$ & $15.50 \pm 1.90$ & $32.97 \pm 4.27$ & $36.38 \pm 7.70$ \\
Current dose of L-thyroxine $(\mu \mathrm{g} /$ day) & None & $110.95 \pm 5.25$ & $88.46 \pm 1.55$ & None \\
\hline Data are expressed as mean \pm standard deviation & & &
\end{tabular}




\section{PCR array}

The cDNA was then used with RTI Profiler PCR Array (QIAGEN, Cat. no. PAHS-031Z) in combination with RTI SYBR ${ }^{\circledR}$ Green qPCR Mastermix (QIAGEN, Cat. no. 330504), following the complete RT2 Profiler PCR Array procedure (www.qiagen.com). Samples were assigned to control and study groups. CT values were normalized based on the automatic selection from the full panel of reference genes. Any $\mathrm{Ct}$ value $>35$ was considered to be a negative call. The RT2 Profiler, PCR Array data analysis software, calculates the fold change based on the widely used and agreed upon $\Delta \Delta \mathrm{Ct}$ method. The data analysis web portal calculates fold change/regulation using delta-delta CT method, in which delta CT is calculated between the gene of interest $(\mathrm{GOI})$ and an average of reference genes (HKG), followed by delta-delta CT calculations (delta CT [Test Group]-delta CT [Control Group]). Fold change is then calculated using $2^{\wedge}$ (-delta-delta CT) formula. This data analysis report was exported from the QIAGEN web portal at GeneGlobe. The software allows defining the best reference genes for normalization.

A list of neurotrophin and receptor pathwayfocused genes selected for this research is given in Table 2.

Table 2: Neurotrophins and receptors pathway-focused genes

\begin{tabular}{|c|c|c|c|}
\hline UniGene & RefSeq & Symbol & Description \\
\hline Hs. 377783 & NM_001118 & ADCYAP1R1 & $\begin{array}{l}\text { Adenylate cyclase activating polypeptide } 1 \\
\text { (pituitary) receptor type I }\end{array}$ \\
\hline Hs. 115617 & NM_001882 & CRHBP & $\begin{array}{l}\text { Corticotropin-releasing hormone-binding } \\
\text { protein }\end{array}$ \\
\hline Hs. 417628 & NM_004382 & CRHR1 & Corticotropin-releasing hormone receptor 1 \\
\hline Hs. 729970 & NM_001883 & CRHR2 & Corticotropin-releasing hormone receptor 2 \\
\hline Hs. 593446 & NM_006654 & FRS2 & Fibroblast growth factor receptor substrate 2 \\
\hline Hs. 194208 & NM_006653 & FRS3 & Fibroblast growth factor receptor substrate 3 \\
\hline Hs. 46894 & NM_004960 & FUS & Fused in sarcoma \\
\hline Hs. 388347 & NM_005264 & GFRA1 & GDNF family receptor alpha 1 \\
\hline Hs. 441202 & NM_001495 & GFRA2 & GDNF family receptor alpha 2 \\
\hline Hs. 151413 & NM 004124 & GMFB & Glia maturation factor, beta \\
\hline Hs. 5210 & NM_004877 & GMFG & Glia maturation factor, gamma \\
\hline Hs. 5258 & NM_006986 & MAGED1 & Melanoma antigen family $\mathrm{D}, 1$ \\
\hline Hs. 2561 & NM 002506 & NGF & Nerve growth factor (beta polypeptide) \\
\hline Hs. 7303 & NM_022002 & NR1I2 & $\begin{array}{l}\text { Nuclear receptor subfamily } 1 \text {, group I, } \\
\text { member } 2\end{array}$ \\
\hline Hs. 408515 & NM_013982 & NRG2 & Neuregulin 2 \\
\hline Hs. 732438 & NM_138573 & NRG4 & Neuregulin 4 \\
\hline Hs. 266902 & NM_006179 & NTF4 & Neurotrophin 4 \\
\hline Hs. 2090 & NM_000956 & PTGER2 & $\begin{array}{l}\text { Prostaglandin E receptor } 2 \text { (subtype EP2), } \\
53 \mathrm{kDa}\end{array}$ \\
\hline Hs. 633653 & NM_016157 & TRO & Trophinin \\
\hline Hs. 587325 & NM_003378 & VGF & VGF nerve growth factor inducible \\
\hline
\end{tabular}

\section{Statistical analysis of PCR array data}

The RT2 Profiler PCR Array Data Analysis software does not perform any statistical analysis beyond the calculation of $p$-values using a Student's t-test (two-tail distribution and equal variances between the two samples) based on the triplicate $2^{\wedge}(-\Delta C T)$ values for each gene in the experimental group compared to the control group. The Microarray Quality Control published results indicate that a ranked list of genes based on fold-change and associated p-value calculation was sufficient to demonstrate reproducible results across multiple microarrays and PCR Arrays, including the RT2 Profiler PCR arrays.

\section{Ethical approval}

The ethical principles contained in the Declaration of Human Rights adopted in Helsinki in 1975 , and revised in 2008, were fully respected in our study. The subjects enrolled voluntarily participated in this study and completed and signed written informed consent. The protocol of study was approved by the local ethics committees of I. Horbachevsky Ternopil National Medical University and Chernivtsi Regional Endocrinology Center.

\section{Results}

Using the Pathway-Focused PCR Array Profiling (Neurotrophins and Receptors RT2 Profiler PCR Array), we examined the neurotrophins and receptors pathway-focused genes expression of patients with primary hypothyroidism as a result of AIT and post-operative hypothyroidism and patients with AIT with rising serum autoantibodies, such as anti-Tg and anti-TPO.

The results from RT2 Profiler neurotrophins and receptors pathway-focused genes expression analysis indicated that in Group 1, which includes patients with post-operative hypothyroidism, the expression of a lot of genes was decreased compared with other groups of patients (Table 3). Reductions in CRHBP (5.03fold), FRS2 (3.3-fold), FRS3 (2.7-fold), GFRA1 (5.5fold), and GFRA2 (4.3-fold) mRNAs were found in Group 1 (Figure 1). The expression of glial maturation factor-beta (GMFB) (4.6-fold), nerve growth factor (NGF) (7.8-fold), and NRG2 (4.6-fold) were markedly decreased too in Group 3 (Table 3 ). As it is shown in Table 3, reductions in NRG4 (3.8-fold), NTF4 (3.6-fold), TRO (6.9- fold), and VGF (5.03-fold) were also found in Group 1. In contrast, the expression of PTGER2 (2.9fold) was increased (Figure 1).

Table 3: Differential expression of mRNA neurotrophins and receptors pathway-focused genes in patients with different thyroid pathology

\begin{tabular}{llll}
\hline Symbol & \multicolumn{3}{l}{ Up-down regulation (comparing to control group) } \\
\cline { 2 - 4 } & Group 1 & Group 2 & Group 3 \\
\cline { 2 - 4 } & Fold regulation & Fold regulation & Fold regulation \\
\hline ADCYAP1R1 & $-1.2988(p=0.19)$ & $1.0694(p=0.74)$ & $1.03(p=0.88)$ \\
CRHBP & $-5.0298(p=0.000153)$ & $-4.5416(p=0.000089)$ & $7.0422(p=0.005)$ \\
CRHR1 & $-1.0525(p=0.204006)$ & $-1.052(p=0.435348)$ & $-1.0772(p=0.061173)$ \\
CRHR2 & $-1.05(p=0.204)$ & $-1.05(p=0.435)$ & $-1.08(p=0.06)$ \\
FRS2 & $-3.29(p=0.01)$ & $-1.25(p=0.288)$ & $12.17(p=0.025)$ \\
FRS3 & $-2.733(p=0.008)$ & $-1.248(p=0.099)$ & $7.742(p=0.04)$ \\
FUS & $1.0789(p=0.648)$ & $1.1702(p=0.324)$ & $-1.4647(p=0.198)$ \\
GFRA1 & $-5.49(p=0.0002)$ & $-5.92(p=0.0015)$ & $3.45(p=0.012)$ \\
GFRA2 & $-4.32(p=0.00038)$ & $-3.94(p=0.0016)$ & $-3.66(p=0.0017)$ \\
GMFB & $-4.63(p=0.0145)$ & $-5.96(p=0.0036)$ & $13.42(p=0.0126)$ \\
GMFG & $-1.14(p=0.343075)$ & $-1.59(p=0.298804)$ & $-1.32(p=0.096805)$ \\
MAGED1 & $-1.05(p=0.204006)$ & $-1.05(p=0.435348)$ & $-1.077(p=0.061173)$ \\
NGF & $-7.84(p=0.0007)$ & $-3.83(p=0.001)$ & $-4.076(p=0.0009)$ \\
NRG2 & $-4.63(p=0.001)$ & $-1.127(p=0.365)$ & $-4.65(p=0.002)$ \\
NRG4 & $-3.847(p=0.007)$ & $8.92(p=0.004)$ & $14.41(p=0.003)$ \\
NTF4 & $-3.58(p=0.0036)$ & $-1.089(p=0.875)$ & $-3.78(p=0.0038)$ \\
PTGER2 & $2.94(p=0.0059)$ & $-5.72(p=0.001)$ & $-6.15(p=0.0005)$ \\
TRO & $-6.95(p=0.002)$ & $6.44(p=0.0008)$ & $7.37(p=0.0001)$ \\
VGF & $-5.03(p=0.0004)$ & $-4.73(p=0.0003)$ & $6.03(p=0.002)$ \\
\hline
\end{tabular}




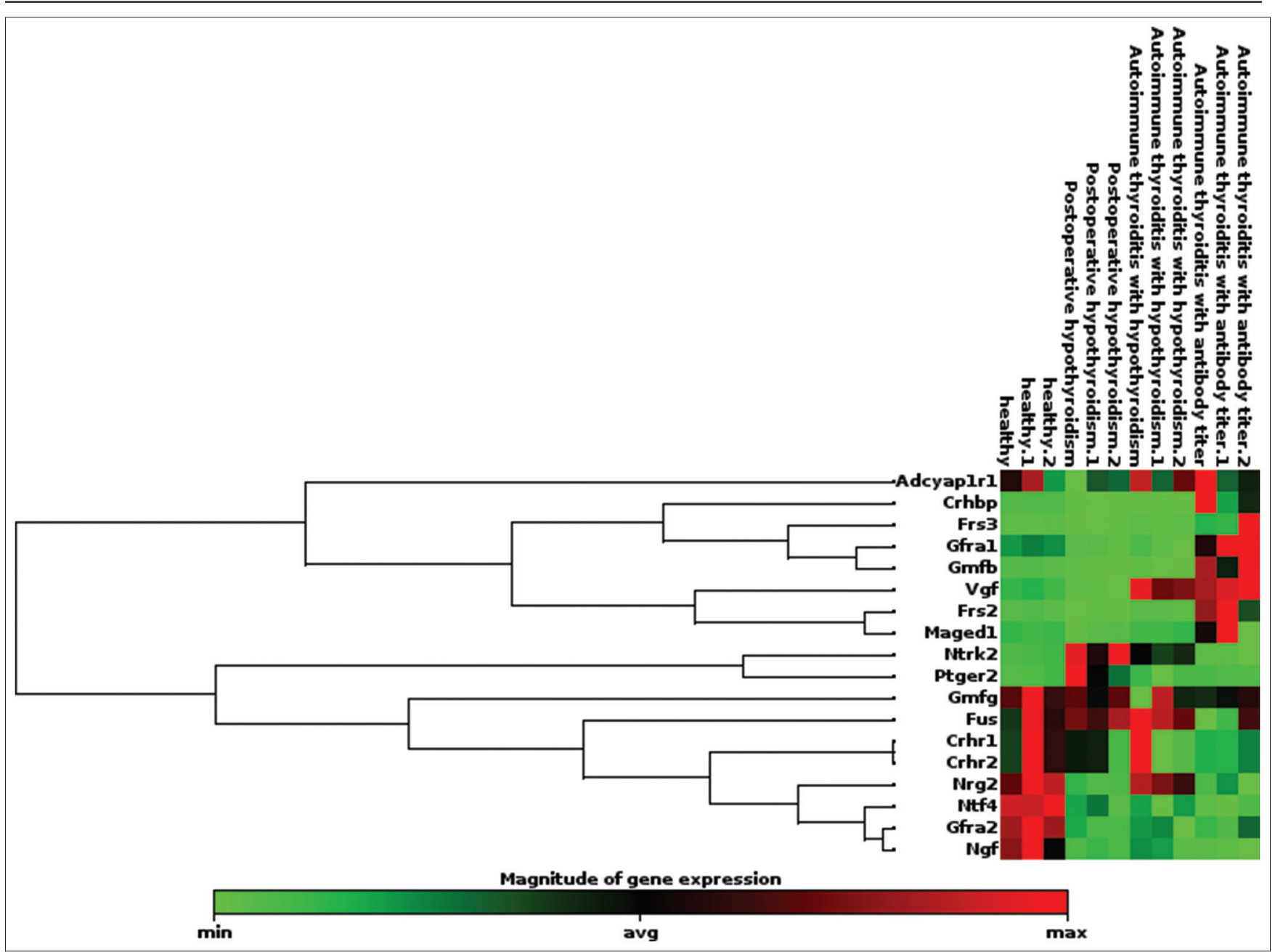

Figure 1: Clustergram expression of mRNA Neurotrophins \& receptors pathway-focused genes in patients with different thyroid pathology

In patients with hypothyroidism as a result of AIT (Group 2), the expression of neurotrophins and receptors pathway-focused genes changed as follows: The decrease in the expressions of CRHBP (4.5fold), GFRA1 (5.9-fold), GFRA2 (3.9-fold), and GMFB (5.9-fold) were observed. As it is shown in Table 3, reductions in NGF (3.8-fold), PTGER2 (5.7-fold), and VGF (4.7-fold) mRNAs were also found in Group 2, whereas the expressions of TRO (6.4-fold) and NRG4 (8.9-fold) were increased (Figure 1).

We noted that in Group 3 which includes patients with AIT with rising serum anti-Tg and anti-TPO autoantibodies that mRNA level of CRHBP (7.04-fold), FRS2 (12.2-fold), and FRS3 (7.7-fold) were significantly increased (Figure 1). Reductions in GFRA2 (3.7-fold), NGF (4.1-fold), NRG2 (4.7-fold), NTF4 (3.8-fold), and NGF (4.1-fold) PTGER (6.1-fold) mRNAs were found in Group 3. The expression of GFRA1 (3.5-fold), GMFB (13.4-fold), and NRG4 (14.4-fold) were markedly increased in Group 3 (Figure 1). What is more, the expression of TRO (7.4-fold) and VGF (6.03-fold) was increased too (Figure 1).

Besides, we found that ADCYAP1R1, CRHR1, CRHR2, FUS, GMFG, and MAGED1 did not change their expression in all groups of patients.
The $p$-values are calculated based on a Student's t-test of the replicate $2^{\wedge}(-$ Delta CT) values for each gene in the control group and patients groups.

\section{Discussion}

Neurotrophins are a family of neurotrophic factors essential for the development of the vertebrate nervous system. They regulate neuron differentiation, survival, or death during embryonic and postnatal development and are involved in neuronal maintenance later in life [13]. The first such substance to be identified, and the prototype of the class was NGF [14]. The neurotrophins are expressed in a broad array of tissues, consistent with the view that they mainly function as target-derived survival factors [15].

Although the developmental effects of $\mathrm{TH}$ have been well established, its impacts on the adult brain are relatively poorly understood [16]. While the adult mammalian brain does not exhibit the severe morphological defects associated with developmental hypothyroidism, TH deficiency in adulthood has 
been linked to cognitive dysfunction and depressed mood [17]. For example, adult-onset hypothyroidism in humans is linked to impaired learning, verbal fluency, and spatial tasks [18], as well as an increased risk of depression [19]. This suggests that thyroid dysfunction in adulthood may result in morphological changes to the brain regions associated with learning, memory, and mood, such as the hippocampus.

In many body tissues, neurotrophins are produced by a variety of non-neuronal cell types such as immune cells, adipocytes, endothelia, epithelia, fibroblasts, keratinocytes, and endocrine cells [20]. Variations in neurotrophin concentrations found in the systemic blood circulation indicate their both vascular and peripheral production. Neurotrophins can cross through blood-brain barrier [21], [22], although the peripheral expression of neurotrophic factors in different tissues (the thymus, heart, liver, pancreas, spleen, kidney, and adrenal glands) has been also reported [23], [24]. It has been suggested that altered RNA and protein expression of the neurotrophic factors in the peripheral tissues can indicate brain disorders [25]

Corticotropin-releasing hormone $(\mathrm{CRH})$ is a key regulator of the stress response [26]. This peptide controls the hypothalamic-pituitary-adrenal axis as well as a variety of behavioral and autonomic stress responses. The $\mathrm{CRH}$ system in vertebrates includes two receptors (CRH-R1 and $\mathrm{CRH}-\mathrm{R} 2)$, which show dissimilar expression patterns in the brain and periphery [27]. We found that $\mathrm{CRH}-\mathrm{R} 1$ and $\mathrm{CRH}-\mathrm{R} 2$ expressions did not significantly change in all groups of patients.

The CRH system also involves an evolutionarily conserved corticotropin-releasing factor-binding protein (CRHBP), a high-affinity binding protein that modulates $\mathrm{CRH}$-mediated activation of $\mathrm{CRH}$ receptors in the brain and periphery and the primary mediator of the mammalian neuroendocrine and behavioral response to stress [28], encoded by CRHBP gene. In humans, CRHBP is widely distributed throughout the body and is found in several brain regions, including the cerebral cortex, the hippocampus, amygdala, lateral septal nucleus, and a variety of midbrain structures [29]. Early studies indicated that approximately $40-60 \%$ of $\mathrm{CRH}$ in the human brain is bound by CRHBP, suggesting its role in limiting the bioavailability of $\mathrm{CRH}$ and reducing $\mathrm{CRH}$ receptor activation [30]. One study found that CRHBP plasma levels were elevated in inflammatory conditions such as rheumatoid arthritis and septicemia, indicating that CRHBP may be positively regulated by inflammatory stressors [26]. In this study, we found a significant decrease in the expression of CRHBP in Groups 1 and 2. On the other hand, in Group 3, the expression of CRHBP was increased. This suggests suppression of CRHBP expression in the cases of TH deficiency resulting from AIT and post-operative hypothyroidism.

Fibroblast growth factor (FGF) receptor substrates 2 and 3 (FRS2 and FRS3) are two related adapter proteins, sharing $49 \%$ sequence identity and activated by the FGF and NTRK1 receptors [31]. Studies suggest that FRS2 and FRS3 transducers are involved in the thyroid tumorigenesis induced by TRK oncogenes and thus might represent targets for treatment approaches aimed at blocking oncoprotein signaling [32]. Certain factors such as neurotrophins and FGFs can play both neurogenic and synaptic roles [33], [34], [35]. Neurotrophins and FGFs promote postnatal dentate neurogenesis by signaling through their specific receptor subtypes, FGF Receptor 1 (FGFR1), and Neurotrophic Tyrosine Kinase Receptor type 2 (NTRK2 or TrkB) [36]. Specific FGF receptor isoforms (FGFR1b and FGFR2b) are involved in synaptogenesis in CA3 pyramidal neurons, while TrkB was implicated in DGC maturation [34], [35]. In this study, FRS2 and FRS3 expression significantly decreased in the group of patients with post-operative hypothyroidism, while it significantly increased Group 3 , which includes patients with AIT and elevated serum anti-Tg and anti-TPO autoantibodies.

A new family of neurotrophic factors composed of four members, namely, GDNF, NTN, ART, and PSP which other preferentially to GFRa-1, GFRa-2, GFRa-3, and GFRa-4, respectively, has been recently described [37]. Within the CNS, GFRa-1 and GFRa-2 show a widespread expression [38]. A dramatic increase in GFRa-2 mRNA that was triggered after short-term treatment with THs suggests a specific action through high affinity receptors for this gene [37]. $\mathrm{TH}$ receptors were detected in glial cells [39] and T3 affects the development of both astrocytes [40] and oligodendrocytes [41], indicating that T3 may control the expression of GFRa2 in these two cell types.

The results of our study indicated that the expression of GFRA2 was significantly decreased in all groups of patients. At the same time, the patients with primary hypothyroidism resulting from AIT and post-operative hypothyroidism had significantly lower expression of GFRA1, while in the group of patients with AIT and rising serum anti-Tg and anti-TPO autoantibodies, the levels of GFRA1 mRNA were significantly increased.

GMFB is a highly conserved brain-enriched protein implicated in immunoregulation, neuroplasticity, and apoptosis, processes central to neural injury and repair following cerebral ischemia. Although GMFB is expressed in multiple organs, the expression is enriched in brain tissue and relatively stable in adults [42], [43]. Plasma GMFB levels can serve as a convenient noninvasive addition to neuroimaging for stroke diagnosis and prognosis [44]. The expression of GMFB is also altered in several neurodegenerative diseases [45], suggesting that GMFB as a broadly applicable disease biomarker. Peak GMFB expression correlates with learning and memory formation in rats [46]. Further, the neurite localization of this protein is also consistent with its role in neural plasticity. In this study, we found 
that GMFB was downregulated in Groups 1 and 2. Patients with AIT and rising serum autoantibodies had significantly higher expression of GMFB.

The biological effect of the neurotrophins is mediated through the high-affinity tropomyosin-related family of tyrosine receptor kinases (TrkA, TrkB, and TrkC) and the p75 neurotrophin receptor which can bind all neurotrophins with low affinity [21]. These receptors can either enhance or inhibit each other's actions to mediate neurotrophic effect. NGF, neurotrophin (NT-3), and NT-4 are expressed by neurons, microglial cells, and astrocytes, as well as activated lymphocytes [47]. NT-4 levels were shown to correlate with psychosocial functioning in patients with bipolar disorder in remission [48]. A recent meta-analysis conducted by Tseng et al. found increased NT-3 and NT-4 levels in patients with bipolar disorder in a depressed state when compared to healthy controls. This difference was significantly associated with the duration of illness [48].

Different inflammatory and autoimmune diseases lead to altered expression of NGF. Increased anti-NGF antibody levels have been detected in patients with rheumatoid arthritis, systemic lupus erythematosus, and thyroiditis and are thought to contribute to the immune dysfunction and nerve damage observed in these diseases [49]. NGF is expressed not only in the neuronal but also non-neuronal cells (epithelial, endothelial and skeletal muscle cells, fibroblasts, adipocytes, and bone marrow-derived cells); it can modify the local immune responses promoting T-helper 2 dominance with the release of various cytokines, chemokines, and prostaglandin derivatives [50]. NGF is involved in both neuronal cell function and inflammatoryimmune cell activity, contributing to the development and maintenance of chronic inflammation [51]. NGF secretion increases in hypothyroidism [52]. In our study, we found reduced levels of NGF mRNA in all groups of patients. This is in contrast to the expression of NTF4, which was reduced only in Groups 1 and 3.

The neuregulins (NRGs) are cell-cell signaling proteins that are ligands for tyrosine kinase receptors of the ErbB family. The neuregulin gene family has four members: NRG1, NRG2, NRG3, and NRG4 [53]. NRGs and their receptors are widely expressed in the postnatal nervous system [54]; NRG expression in the brain is upregulated by its activity; and NRGs can inhibit long-term potentiation (LTP), a mechanism involves in learning [55]. In this study, we determined that patients with post-operative hypothyroidism had a significantly increased expression of NRG2 and NRG4. The NRG2 mRNA levels decreased, while NRG4 mRNA levels significantly increased in the patients with elevated serum autoantibodies anti-Tg and anti-TPO.

EP2 receptor plays an important role in hippocampal LTP and spatial learning. PGE2 induces a synaptic response through its action on a pre-synaptic EP2 receptor [56]. This means that PGE2-EP2 signaling is important for hippocampal long-term synaptic plasticity and cognitive function. In this study, PTGER2 mRNA increased in Group 1 which included patients with post-operative hypothyroidism, while PTGER2 expression decreased in the group of AIT patients with elevated serum autoantibodies, such as anti-Tg and anti-TPO and in the patients with hypothyroidism as a result of AIT.

Trophinin (TRO) and bystin are highly expressed in the SVZ and RMS of the adult rat brain [57]. Since TRO is expressed on plasma membranes and in the cytoplasm of type $\mathrm{C}$ cells in the SVZ and in migrating neuroblasts in the RMS, it is possible that it interacts with the extracellular matrix promoting chain migration of neuroblasts along the RMS toward the olfactory bulb. We observed a decrease in expression of TRO in patients with post-operative hypothyroidism. On the contrary, TRO expression considerably increased in Groups 2 and 3.

VGF nerve growth factor inducible (VGF) was first identified as a neuropeptide, the expression of which is induced by NGF [58]. VGF expression is also induced by several other growth factors, such as brainderived neurotrophic factor (BDNF) and NT-3 [59]. VGF is synthesized in neuronal and neuroendocrine cells as well as in the CNS, especially in the cerebral cortex, hippocampus, and hypothalamus [60], [61]. Studies show that VGF-derived peptides are involved in a number of functions in the CNS and peripheral tissues. For instance, in patients with the major depressive disorder who were drug-free for at least 2 weeks, VGF mRNA levels in leukocytes were significantly reduced, by approximately $50 \%$, compared to healthy subjects [62]. In another study, VGF levels in serum and prefrontal cortex decreased in patients with the major depressive disorder [63]. In this study, patients with hypothyroidism as a result of AIT and post-operative hypothyroidism VGF expression was reduced, while it was significantly increased in the group of AIT patients with elevated serum autoantibodies, such as anti-Tg and anti-TPO.

\section{Conclusion}

In summary, the analysis of gene expression of neurotrophins and their receptors showed that CRHBP, FRS2, FRS3, GFRA1, GFRA2, GMFB, NGF, NRG2, NRG4, NTF4, TRO, and VGF significantly decreased their expression in Group 3, which includes the patients with post-operative hypothyroidism. The patients with primary hypothyroidism stemming from AIT had significantly reduced expression of CRHBP, GFRA1, GFRA2, GMFB, NGF, PTGER2, and VGF, while the expression of NRG4 and TRO increased. In Group 3 , which includes the patients with AIT and elevated serum anti-Tg and anti-TPO autoantibodies, the 
mRNA levels of GFRA2, NGF, NRG2, NTF4, NGF, and PTGER were reduced, and the expression of CRHBP, FRS2, FRS3 GFRA1, GMFB, NRG4, TRO, and VGF significantly increased. In addition, the expression of ADCYAP1R1, CRHR1, CRHR2, FUS, GMFG, and MAGED1 did show a significant change in all groups of patients. These results indicate significant variability in the transcriptional activity of the genes of encoding for neurotrophins and their receptors in the peripheral blood in people with thyroid diseases.

\section{References}

1. Vanderpump MP, Tunbridge WM. Epidemiology and prevention of clinical and subclinical hypothyroidism. Thyroid. 2002;12(10):83947. https://doi.org/10.1089/105072502761016458

PMid: 12487765

2. Montero-Pedrazuela A, Venero $\mathrm{C}$, Lavado-Autric R, FernándezLamo I, García-Verdugo JM, Bernal J, et al. Modulation of adult hippocampal neurogenesis by thyroid hormones: implications in depressive-like behavior. Mol Psychiatry. 2006;11(4):361-71. https://doi.org/10.1038/sj.mp.4001802

PMid:16446739

3. Zhang L, Blomgren K, Kuhn HG, Cooper-Kuhn CM. Effects of postnatal thyroid hormone deficiency on neurogenesis in the juvenile and adult rat. Neurobiol Dis. 2009;34(2):366-74. https:// doi.org/10.1016/j.nbd.2009.02.006

PMid:19233274

4. Rovet JF, Ehrlich R. Psychoeducational outcome in children with early-treated congenital hypothyroidism. Pediatrics. 2000;105(3 Pt 1):515-22. https://doi.org/10.1542/peds.105.3.515 PMid:10699102

5. Bilous I, Pavlovych L, Krynytska I, Marushchak M, Kamyshnyi A. Apoptosis and cell cycle pathway-focused genes expression analysis in patients with different forms of thyroid pathology. Open Access Maced J Med Sci. 2020;8(B):784-92. https://doi. org/10.3889/oamjms.2020.4760

6. Bilous II, Korda MM, Krynytska IY, Kamyshnyi AM. Nerve impulse transmission pathway-focused genes expression analysis in patients with primary hypothyroidism and autoimmune thyroiditis. Endocr Regul. 2020;54(2):109-18. https://doi.org/10.2478/enr-2020-0013

PMid:32597152

7. Bilous I, Pavlovych L, Kamyshnyi A. Primary hypothyroidism and autoimmune thyroiditis alter the transcriptional activity of genes regulating neurogenesis in the blood of patients. Endocr Regul. 2021;55(1):5-15. https://doi.org/10.2478/enr-2021-0002 PMid:33600668

8. Degen A, Krynytska I, Kamyshnyi A. Changes in the expression of regulatory MicroRNAs miR-21 and miR-155-in gut-associated lymphoid tissue cells of rats with streptozotocin-induced diabetes and after the administration of a non-selective TNF-A blocker. Rom J Diabetes Nutr Metab Dis. 2020;27(2):128-34.

9. Degen AS, Krynytska IY, Kamyshnyi AM. Changes in the transcriptional activity of the entero-insular axis genes in streptozotocin-induced diabetes and after the administration of TNF- $\alpha$ non-selective blockers. Endocr Regul. 2020;54(3):16071. https://doi.org/10.2478/enr-2020-0019 PMid:32857721

10. Putilin DA, Evchenko SY, Fedoniuk LY, Tokarskyy OS,
Kamyshny OM, Migenko LM, et al. The influence of metformin to the transcriptional activity of the mTOR and FOX3 genes in parapancreatic adipose tissue of streptozotocin-induced diabetic rats. J Med Life. 2020;13(1):50-5. https://doi.org/10.1530/ endoabs.49.ep455

PMid:32341701

11. ProzorovaT, Tokarskyy O, Fedoniuk L, Harbuzova V, Morozova O, Kamyshny A, et al. Changes in the transcriptional activity of the lymphocyte homing regulatory genes Madcam1, Cxcr3, Ccr7 and S1pr1 affect structure of the population of T-Bet+, Roryt+ and Foxp3+ cells in mesenteric lymph nodes. Rom J Diabetes Nutr Metab Dis 2020;27(3):185-90. https://doi. org/10.25040/ecpb2017.01.023

12. Garber JR, Cobin RH, Gharib H, Hennessey JV, Klein I, Mechanick JI, et al. Clinical practice guidelines for hypothyroidism in adults: Cosponsored by the American association of clinical endocrinologists and the American thyroid association. Endocr Pract. 2012;18(6):988-1028. https://doi.org/10.4158/ep12280.gl PMid:23246686

13. Bradshaw RA, Pundavela J, Biarc J, Chalkley RJ, Burlingame AL, Hondermarck $H$. NGF and ProNGF: Regulation of neuronal and neoplastic responses through receptor signaling. Adv Biol Regul. 2015;58:16-27. https://doi. org/10.1016/j.jbior.2014.11.003 PMid:25491371

14. Levi-Montalcini R. The nerve growth factor 35 years later. Science. 1987;237(4819):1154-62. https://doi.org/10.1126/ science. 3306916

PMid:3306916

15. Hempstead BL. Deciphering proneurotrophin actions. Handb Exp Pharmacol. 2014;220:17-32.

PMid:24668468

16. Desouza LA, Ladiwala U, Daniel SM, Agashe S, Vaidya RA Vaidya VA. Thyroid hormone regulates hippocampal neurogenesis in the adult rat brain. Mol Cell Neurosci. 2005;29(3):414-26. https://doi.org/10.1016/j.mcn.2005.03.010 PMid:15950154

17. Dugbartey AT. Neurocognitive aspects of hypothyroidism. Arch Intern Med. 1998;158(13):1413-8. https://doi.org/10.1001/ archinte.158.13.1413

PMid:9665349

18. Baldini IM, Vita A, Mauri MC, Amodei V, Carrisi M, Bravin S, et al. Psychopathological and cognitive features in subclinical hypothyroidism. Prog Neuropsychopharmacol Biol Psychiatry. 1997;21(6):925-35. https://doi.org/10.1016/ s0278-5846(97)00089-4 PMid:9380789

19. Haggerty JJ Jr., Stern RA, Mason GA, Beckwith J, Morey CE, Prange AJ Jr. Subclinical hypothyroidism: A modifiable risk factor for depression? Am J Psychiatry. 1993;150(3):508-10. PMid:8434671

20. Nockher WA, Renz H. Neurotrophins in clinical diagnostics: Pathophysiology and laboratory investigation. Clin Chim Acta. 2005;352(1-2):49-74. https://doi.org/10.1016/j. cccn.2004.10.002 PMid: 15653100

21. Skibinska M, Kapelski P, Rajewska-RagerA, SzczepankiewiczA Narozna B, Duda J, et al. Correlation of metabolic parameters, neurotrophin-3, and neurotrophin-4 serum levels in women with schizophrenia and first-onset depression. Nord J Psychiatry. 2019;73(2):96-103. https://doi.org/10.1080/08039488.2018.156 3213 PMid:30654674

22. Poduslo JF, Curran GL. Permeability at the blood-brain and blood-nerve barriers of the neurotrophic factors: NGF, CNTF, 
NT-3, BDNF. Brain Res Mol Brain Res. 1996;36(2):280-6. https://doi.org/10.1016/0169-328x(95)00250-v PMid:8965648

23. Lommatzsch $M$, Quarcoo $D$, Schulte-Herbrüggen $O$, Weber $\mathrm{H}$, Virchow JC, Renz H, et al. Neurotrophins in murine viscera: A dynamic pattern from birth to adulthood. Int J Dev Neurosci. 2005;23(6):495-500. https://doi.org/10.1016/j. ijdevneu.2005.05.009

PMid:15978771

24. Katoh-Semba $R$, Kaisho $Y$, Shintani A, Nagahama $M$, Kato K. Tissue distribution and immunocytochemical localization of neurotrophin-3 in the brain and peripheral tissues of rats. J Neurochem. 1996;66(1):330-7. https://doi. org/10.1046/j.1471-4159.1996.66010330.x PMid:8522971

25. Elfving $B$, Plougmann $P H$, Müller $H K$, Mathé $A A$, Rosenberg $R$, Wegener $G$. Inverse correlation of brain and blood BDNF levels in a genetic rat model of depression. Int J Neuropsychopharmacol. 2010;13(5):563-72. https://doi. org/10.1017/s1461145709990721

PMid: 19796445

26. Ketchesin KD, Stinnett GS, SeasholtzAF. Corticotropin-releasing hormone-binding protein and stress: From invertebrates to humans. Stress. 2017;20(5):449-64. https://doi.org/10.1080/10 253890.2017.1322575

PMid:28436309

27. Hillhouse EW, Grammatopoulos DK. The molecular mechanisms underlying the regulation of the biological activity of corticotropin-releasing hormone receptors: Implications for physiology and pathophysiology. Endocr Rev. 2006;27(3):26086. https://doi.org/10.1210/er.2005-0034

PMid:16484629

28. Enoch MA, Shen PH, Ducci F, Yuan Q, Liu J, White KV, et al. Common genetic origins for EEG, alcoholism and anxiety: The role of CRH-BP. PLoS One. 2008;3(10):e3620. https://doi. org/10.1371/journal.pone. 0003620

PMid: 18974851

29. Chan RK, Vale WW, Sawchenko PE. Paradoxical activational effects of a corticotropin-releasing factor-binding protein "ligand inhibitor" in rat brain. Neuroscience. 2000;101(1):115-29. https:// doi.org/10.1016/s0306-4522(00)00322-5

PMid:11068141

30. Behan DP, Khongsaly O, Owens MJ, Chung HD, Nemeroff CB, De Souza EB. Corticotropin-releasing factor (CRF), CRFbinding protein (CRF-BP), and CRF/CRF-BP complex in Alzheimer's disease and control postmortem human brain. J Neurochem. 1997;68(5):2053-60. https://doi. org/10.1046/j.1471-4159.1997.68052053.x

PMid:9109532

31. Meakin SO, MacDonald JI, Gryz EA, Kubu CJ, Verdi JM. The signaling adapter FRS-2 competes with Shc for binding to the nerve growth factor receptor TrkA. A model for discriminating proliferation and differentiation. J Biol Chem. 1999;274(14):986170. https://doi.org/10.1074/jbc.274.14.9861

PMid:10092678

32. Ranzi V, Meakin SO, Miranda C, Mondellini P, Pierotti MA, Greco A. The signaling adapters fibroblast growth factor receptor substrate 2 and 3 are activated by the thyroid TRK oncoproteins. Endocrinology. 2003;144(3):922-8. https://doi. org/10.1210/en.2002-221002

PMid:12586769

33. Nandi S, Alviña K, Lituma PJ, Castillo PE, Hébert JM. Neurotrophin and FGF signaling adapter proteins, FRS2 and FRS3, regulate dentate granule cell maturation and excitatory synaptogenesis. Neuroscience. 2018;369:192-201. https://doi. org/10.1016/j.neuroscience.2017.11.017

PMid:29155277

34. Dabrowski A, Terauchi A, Strong C, Umemori H. Distinct sets of FGF receptors sculpt excitatory and inhibitory synaptogenesis. Development. 2015;142(10):1818-30. https://doi.org/10.1242/ dev. 115568

PMid:25926357

35. Danzer SC, Kotloski RJ, Walter C, Hughes M, McNamara JO Altered morphology of hippocampal dentate granule cell presynaptic and postsynaptic terminals following conditional deletion of TrkB. Hippocampus. 2008;18(7):668-78. https://doi. org/10.1002/hipo.20426

PMid:18398849

36. Li Y, Luikart BW, Birnbaum S, Chen J, Kwon CH, Kernie SG et al. TrkB regulates hippocampal neurogenesis and governs sensitivity to antidepressive treatment. Neuron. 2008;59(3):399412. https://doi.org/10.1016/j.neuron.2008.10.021 PMid:18701066

37. Rémy S, Naveilhan P, Brachet P, Neveu I. Differential regulation of GDNF, neurturin, and their receptors in primary cultures of rat glial cells. J Neurosci Res. 2001;64(3):242-51. https://doi. org/10.1002/jnr.1072

PMid:11319768

38. Widenfalk J, Nosrat C, Tomac A, Westphal H, Hoffer B, Olson L. Neurturin and glial cell line-derived neurotrophic factor receptor-beta (GDNFR-beta), novel proteins related to GDNF and GDNFR-alpha with specific cellular patterns of expression suggesting roles in the developing and adult nervous system and in peripheral organs. J Neurosci. 1997;17(21):8506-19. https://doi.org/10.1523/jneurosci.17-21-08506.1997 PMid:9334423

39. Carlson DJ, Strait KA, Schwartz HL, Oppenheimer JH. Thyroid hormone receptor isoform content in cultured Type 1 and Type 2 astrocytes. Endocrinology. 1996;137(3):911-7. https://doi. org/10.1210/endo.137.3.8603603 PMid:8603603

40. Paul S, Das S, Poddar R, Sarkar PK. Role of thyroid hormone in the morphological differentiation and maturation of astrocytes: Temporal correlation with synthesis and organization of actin. Eur J Neurosci. 1996;8(11):2361-70. https://doi. org/10.1111/j.1460-9568.1996.tb01199.x

PMid:8950100

41. Rodríguez-Peña A. Oligodendrocyte development and thyroid hormone. J Neurobiol. 1999;40(4):497-512.

PMid:10453052

42. Selvakumar GP, lyer SS, Kempuraj D, Raju M, Thangavel R, Saeed D, et al. Glia maturation factor dependent inhibition of mitochondrial PGC- $1 \alpha$ triggers oxidative stress-mediated apoptosis in N27 rat dopaminergic neuronal cells. Mol Neurobiol. 2018;55(9):7132-52. https://doi.org/10.1007/ s12035-018-0882-6

\section{PMid:29383690}

43. Inagaki M, Aoyama M, Sobue $\mathrm{K}$, Yamamoto $\mathrm{N}$, Morishima $\mathrm{T}$ Moriyama A, et al. Sensitive immunoassays for human and rat GMFB and GMFG, tissue distribution and age-related changes. Biochim Biophys Acta. 2004;1670(3):208-16. https://doi. org/10.1016/j.bbagen.2003.12.006 PMid:14980447

44. Yuan Z, Yu Z, Zhang Y, Yang H. Analysis of the clinical diagnostic value of GMFB in cerebral infarction. Curr Pharm Biotechnol. 2020;21(10):955-63. https://doi.org/10.2174/138920102166620 0210102425 PMid:32039676

45. Fan J, Fong $\mathrm{T}$, Chen $\mathrm{X}$, Chen $\mathrm{C}$, Luo $\mathrm{P}$, Xie H. Glia maturation factor- $\beta$ : A potential therapeutic target in neurodegeneration and 
neuroinflammation. Neuropsychiatr Dis Treat. 2018;14:495-504. https://doi.org/10.2147/ndt.s157099

PMid:29445286

46. Rahman A, Khan KM, Al-Khaledi G, Khan I, Al-Shemary T. Over activation of hippocampal serine/threonine protein phosphatases PP1 and PP2A is involved in lead-induced deficits in learning and memory in young rats. Neurotoxicology. 2012;33(3):370-83. https://doi.org/10.1016/j.neuro.2012.02.014 PMid:22387731

47. Barouch R, Appel E, Kazimirsky G, Braun A, Renz H, Brodie C. Differential regulation of neurotrophin expression by mitogens and neurotransmitters in mouse lymphocytes. J Neuroimmunol. 2000;103(2):112-21. https://doi.org/10.1016/ s0165-5728(99)00233-7

PMid:10696906

48. Walz JC, Magalhães PV, Giglio LM, Cunha AB, Stertz L, Fries GR, et al. Increased serum neurotrophin-4/5 levels in bipolar disorder. J Psychiatr Res. 2009;43(7):721-3. https://doi. org/10.1016/s0924-9338(09)70792-8

PMid:19081579

49. Dicou E, Hurez D, Nerrière V. Natural autoantibodies against the nerve growth factor in autoimmune diseases. J Neuroimmunol. 1993;47(2):159-67. https://doi. org/10.1016/0165-5728(93)90026-u

\section{PMid:8370767}

50. Hahn C, Islamian AP, Renz H, Nockher WA. Airway epithelial cells produce neurotrophins and promote the survival of eosinophils during allergic airway inflammation. J Allergy Clin Immunol. 2006;117(4):787-94. https://doi.org/10.1016/j. jaci.2005.12.1339 PMid:16630935

51. Minnone G, De Benedetti F, Bracci-Laudiero L. NGF and its receptors in the regulation of inflammatory response. Int $\mathrm{J} \mathrm{Mol}$ Sci. 2017;18(5):1028. https://doi.org/10.3390/ijms18051028 PMid:28492466

52. Yao M, Dooley PC, Schuijers JA, Grills BL. The effects of hypothyroidism on nerve growth factor and norepinephrine concentrations in weight-bearing and non-weight-bearing bones of rats. J Musculoskelet Neuronal Interact. 2004;4(3):319-24. PMid:15615500

53. Falls DL. Neuregulins: Functions, forms, and signaling strategies. Exp Cell Res. 2003;284(1):14-30. https://doi. org/10.1016/s0014-4827(02)00102-7 PMid:12648463

54. Bermingham-McDonogh $\mathrm{O}, \mathrm{Xu} Y \mathrm{YT}$, Marchionni MA, Scherer SS Neuregulin expression in PNS neurons: Isoforms and regulation by target interactions. Mol Cell Neurosci. 1997;10(3-4):184-95. https://doi.org/10.1006/mcne.1997.0654

PMid:9532580

55. Huang YZ, Won S, Ali DW, Wang Q, Tanowitz M, Du QS, et al Regulation of neuregulin signaling by PSD-95 interacting with ErbB4 at CNS synapses. Neuron. 2000;26(2):443-55. https:// doi.org/10.1016/s0896-6273(00)81176-9 PMid:10839362

56. Yang H, Zhang J, Breyer RM, Chen C. Altered hippocampa long-term synaptic plasticity in mice deficient in the PGE2 EP2 receptor. J Neurochem. 2009;108(1):295-304. https://doi. org/10.1111/j.1471-4159.2008.05766.x PMid:19012750

57. Ma L, Yin M, Wu X, Wu C, Yang S, Sheng J, et al. Expression of trophinin and bystin identifies distinct cell types in the germinal zones of adult rat brain. Eur J Neurosci. 2006;23(9):2265-76. https://doi.org/10.1111/j.1460-9568.2006.04782.x PMid:16706835

58. Levi A, Eldridge JD, Paterson BM. Molecular cloning of a gene sequence regulated by nerve growth factor. Science. 1985;229(4711):393-5. https://doi.org/10.1126/science.3839317 PMid:3839317

59. Bonni A, Ginty DD, Dudek H, Greenberg ME. Serine 133-phosphorylated CREB induces transcription via a cooperative mechanism that may confer specificity to neurotrophin signals. Mol Cell Neurosci. 1995;6(2):168-83. https://doi.org/10.1006/mcne.1995.1015 PMid:7551568

60. van den Pol AN, Bina K, Decavel C, Ghosh P. VGF expression in the brain. J Comp Neurol. 1994;347(3):455-69. https://doi. org/10.1002/cne.903470311

PMid:7822494

61. Snyder SE, Salton SR. Expression of VGF mRNA in the adult rat central nervous system. J Comp Neurol. 1998;394(1):91-105. https://doi.org/10.1002/ (sici)1096-9861(19980427)394:1<91::aid-cne7>3.0.co;2-c PMid:9550144

62. Cattaneo A, Sesta A, Calabrese F, Nielsen G, Riva MA Gennarelli M. The expression of VGF is reduced in leukocytes of depressed patients and it is restored by effective antidepressant treatment. Neuropsychopharmacology. 2010;35(7):1423-8. https://doi.org/10.1038/npp.2010.11

PMid:20164831

63. Chen S, Jiang H, Hou Z, Yue Y, Zhang Y, Zhao F, et al. Higher serum VGF protein levels discriminate bipolar depression from major depressive disorder. J Neurosci Res. 2019;97(5):597606. https://doi.org/10.1002/jnr.24377

PMid:30575991 